\title{
Land suitability assessment for optimum management of water consumption in precise agriculture
}

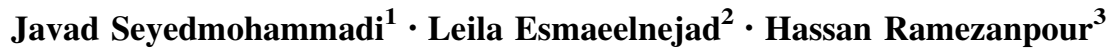

Received: 1 August 2016/Accepted: 13 August 2016/Published online: 1 September 2016

(C) Springer International Publishing Switzerland 2016

\begin{abstract}
Optimum irrigation management is an important factor in precise agriculture. The main objective of this research is to compare different irrigation methods based upon a parametric evaluation system in an area of 41,200 ha in the Rasht region, north Iran. Once the soil properties were analyzed and evaluated, suitability maps were generated for surface, sprinkler and drip irrigation methods using a geographic information system and remote sensing. Parametric methods including Storie and Khidir, were used for land suitability evaluation to propose suitable irrigation system. Khidir method was more accurate than Storie method. The obtained results of khidir method showed that for 40,487.3 ha $(98.3 \%)$ of the study area the drip irrigation method was suitable. Capability ratings were the highest in all soil series for drip irrigation. The results demonstrated that by applying drip irrigation method instead of sprinkler and surface irrigation methods, the arability of $40,487.3$ ha in the Rasht region would improve. The comparison of the different types of irrigation revealed that drip irrigation system was more effective and efficient than the surface and sprinkler irrigation methods and improved land suitability for irrigation purposes. It is of note, however, that the main limiting factors
\end{abstract}

Javad Seyedmohammadi

seyedmohammadi.javad@gmail.com

1 Department of Soil Science, Faculty of Agriculture, University of Tabriz, Tabriz, Iran

2 Department of Soil Science, Faculty of Agricultural Engineering and Technology, College of Agriculture and Natural Resources, University of Tehran, Karaj, Iran

3 Department of Soil Science, Faculty of Agriculture, University of Guilan, Rasht, Iran in using surface, sprinkler and drip irrigation methods in this area were drainage and soil texture.

Keywords Surface irrigation - Sprinkler irrigation · Drip irrigation $\cdot$ Land suitability evaluation $\cdot$ Parametric method

\section{Introduction}

Food security and stability in the world greatly depends on the management of natural resources. Due to the depletion of water resources and an increase in population, the extent of irrigated area per capita is declining and irrigated lands now produce $40 \%$ of the food supply (Fernandez Garcia et al. 2014). Water is an important resource for human society and protection of this natural resource efficiently has become one of the main challenges of this century (Alam and Olsthoorn 2011; Asres 2016). According to Iran's geographic information, the country is located in a semi-arid region on the earth. Therefore, it can easily be claimed that the limitation of water resources is one of the major factors in the agricultural development of Iran (Samian et al. 2015).

Water is a critical resource for farmers, and ensuring access to water is very important for reducing poverty in rural areas because poverty reduction will lead to food security. There is no agriculture and food security without water; this is an important message from a member of the International Federation of Agricultural Producers (2005). Iran, as a developing country, is located in arid and semiarid areas in which water scarcity is a major issue and regarding to the highest level of water shortage is in the agricultural sector, the need for efficient use, or in other words, management of agricultural water is inevitable. Agricultural water management is a systematic approach to 
control water in the farm and it leads to the provision of crop irrigation and drainage while there are physical, social and governmental problems in production systems (Samian et al. 2015). The aim of the effective management of agricultural water is to increase economic performance with reduced consumption of water and energy (Panda et al. 2004; Asres 2016). So, agricultural water management in areas that are facing the problem of water shortage seems to be more important to expect maximum efficiency from the minimum water resources (Surendran et al. 2016).

Consequently, available water resources will not be able to meet various demands in the near future and this will inevitably result into the seeking of newer lands for irrigation in order to achieve sustainable global food security. Land suitability, by definition, is the natural capability of a given land to support a defined use. The process of land suitability classification is the appraisal and grouping of specific areas of land in terms of their suitability for a defined use. According to FAO methodology (FAO 1976) land suitability is strongly related to "land qualities", including erosion resistance, water availability, and flood hazards which are in themselves immeasurable qualities. Since these qualities are derived from "land characteristics', such as slope angle and length, rainfall and soil texture which are measurable or estimable, it is advantageous to use the latter indicators in the land suitability studies, and then use the land parameters for determining the land suitability for irrigation purposes. Sys et al. (1991) suggested a parametric evaluation system for irrigation methods which was primarily based upon physical and chemical soil properties (Dengiz 2006; Liu et al. 2006). In their proposed system, the factors affecting soil suitability for irrigation purposes can be subdivided into four groups:

- Physical properties determining the soil-water relationship in the soil such as permeability and available water content.

- Chemical properties interfering with the salinity/alkalinity status such as soluble salts and exchangeable $\mathrm{Na}$.

- Drainage properties.

- Environmental factors such as slope.

Briza et al. (2001) applied a parametric system to evaluate land suitability for both surface and drip irrigations in the Ben Slimane Province, Morocco, while no highly suitable areas were found in the studied area. The largest part of the agricultural areas was classified as marginally suitable, the most limiting factors being physical parameters such as slope, soil calcium carbonate, and sandy soil texture and soil depth. Bazzani and Incerti (2002) also provided a land suitability evaluation for surface and drip irrigation systems in the province of Larche, Morocco, by using parametric evaluation systems. The results showed a large difference between applying the two different evaluations. The area not suitable for surface irrigation was $29.22 \%$ of total surface and $9 \%$ with the drip irrigation while the suitable area was $19 \%$ versus $70 \%$. Moreover, high suitability was extended on a surface of $3.29 \%$ in the former case and it became $38.96 \%$ in the latter. The main limiting factors were physical limitations such as the slope and sandy soil texture. Bienvenue et al. (2003) evaluated the land suitability for surface (gravity) and drip (localized) irrigation in the Thies, Senegal, by using the parametric evaluation systems. Regarding surface irrigation, there was no area classified as highly suitable (S1). Only $20.24 \%$ of the study area proved suitable (S2, $7.73 \%$ ) or slightly suitable (S3, $12.51 \%$ ). Most of the study area $(57.66 \%)$ was classified as unsuitable (N2). The limiting factor to this kind of land use was mainly the soil drainage status and texture that was mostly sandy while surface irrigation generally requires heavier soils. For drip (localized) irrigation, a good portion $(45.25 \%)$ of the area was suitable (S2) while $25.03 \%$ was classified as highly suitable (S1) and only a small portion was relatively suitable $(\mathrm{N} 1,5.83 \%)$ or unsuitable (N2, $5.83 \%)$. In the latter cases, the handicap was largely due to the shallow soil depth and incompatible texture as a result of a large amount of coarse gravel and/or poor drainage.

Mbodj et al. (2004) performed a land suitability evaluation for two types of irrigation i.e., surface irrigation and drip irrigation, in the Tunisian Oued Rmel Catchment using the suggested parametric evaluation. According to the results, the drip irrigation suitability gave more irrigable areas compared to the surface irrigation practice due to the topographic (slope), soil (depth and texture) and drainage limitations encountered within the surface irrigation suitability evaluation. Barberis and Minelli (2005) provided land suitability classification for both surface and drip irrigation methods in Shouyang county, Shanxi province, China where the study was carried out by a modified parametric system. The results indicated that due to the unusual morphology, the area suitability for the surface irrigation (34\%) is smaller than the surface used for the drip irrigation $(62 \%)$. The most limiting factors were physical parameters including slope and soil depth. Dengiz (2006) also compared different irrigation methods including surface and drip irrigation in the pilot fields of the central research institute, lkizce research farm located in southern Ankara. He concluded that the drip irrigation method increased the land suitability by $38 \%$ compared to the surface irrigation method. The most important limiting factors for surface irrigation in study area were soil salinity, drainage and soil texture, respectively whereas, the major limiting factors for drip or localized irrigation were soil salinity and drainage. Liu et al. (2006) evaluated the land suitability for surface and drip irrigation in the Danling County, Sichuan province China, using a Sys's 
parametric evaluation system. For surface irrigation the most suitable areas $(\mathrm{S} 1)$ represented about $24 \%$ of Danling County, $33 \%$ was moderately suitable (S2), $9 \%$ was classified as marginally suitable (S3), $7 \%$ of the area was founded currently not suitable (N1) and $25 \%$ was very unsuitable for surface irrigation due to their high slope gradient. Drip irrigation was everywhere more suitable than surface irrigation due to the minor environmental impact that it caused. Areas highly suitable for this practice covered $38 \%$ of Danling County; about $10 \%$ was marginally suitable (the steep dip slope and the structural rolling rises of the Jurassic period). The steeper zones of the study area (23\%) were either approximately or totally unsuitable for such a practice.

Azzat et al. (2007) provided a land suitability evaluation for irrigation in the Essaouira Province, Morocco, by using parametric evaluation systems. The largest part of this province was classified as marginally suitable and permanently not suitable. Also, the smallest portion of the cultivated area in this plain (located in the centre) is deemed as being moderately suitable for irrigation. Gizachew and Ndao (2008) evaluated the land suitability for surface (gravity) and drip (localized) irrigation in the Enderta District, Tigray, Ethiopia, using Sys's parametric evaluation systems. Regarding the surface irrigation, the results indicate that $1.5 \%$ of the land is highly suitable (S1), $14.3 \%$ moderate suitable (S2) and $22.3 \%$ slightly suitable (S3). Most of the study area is permanently unsuitable $(55.6 \%)$ and currently unsuitable $(1.2 \%)$. For drip (localized) irrigation, the results show that $15.8 \%$ of the land is highly suitable (S1), $22.8 \%$ moderately suitable (S2), $2.3 \%$ slightly suitable (S3), $49.2 \%$ permanently unsuitable (N2) and $4.9 \%$ currently unsuitable (N1). Drip irrigation can be a good method of irrigation in this region, if it is managed properly (proper design, filters, etc.).

Brou and Woldegiorgis (2010) performed a land suitability evaluation for surface irrigation and drip irrigation in the Kilte Awulaelo District of Tigray region in Ethiopia using the Sys et al. parametric evaluation. The drip irrigation suitability gave more irrigable areas compared to the surface irrigation practice, due to the topographic (slope), soil (depth and texture), surface stoniness and drainage limitations worked out in the surface irrigation suitability evaluation. Diouf and Sarr (2011) compared different irrigation methods including surface and drip irrigation in the Sant'Antioco Island, Southern Sardinia, Italy. The comparison between the two irrigation systems shows that drip irrigation can be a good irrigation method in this region if properly managed (good planning, use of filters, etc.). Albaji et al. (2010) reported that the comparison of the different types of irrigation techniques in Dosalegh plain of Iran revealed that the drip and sprinkler irrigations methods were more effective than that of surface irrigation for improved land productivity. Rabia et al. (2013) studied to spatially evaluate land suitability of Kilte Awulaelo district in Ethiopia, for surface and drip irrigation methods based on GIS and remote sensing approaches. Final suitability maps showed the irregularity of suitability classes' distribution over the study area. Their results showed that only $15 \%$ of the study area was suitable for surface irrigation due to the limitation of the topography and stoniness factors for surface irrigation suitability. They reported that GIS and remote sensing was highly efficient for modeling and developing land suitability maps together with spatially compare land suitability for deferent irrigation methods. Albaji et al. (2014) also demonstrated that sprinkler irrigation was more efficient than the drip and surface irrigation methods and improved land suitability for irrigation purposes in Gotvand Plain of Iran. In the other research that carried out by Albaji et al. (2015) in the Jaizan plain of Iran, the results showed that sprinkler and drip irrigation are the most effective method in this area.

The main objective of this research is to evaluate and compare land suitability for surface, sprinkler and drip irrigation methods based on the parametric evaluation systems for the Rasht Plain, in the Guilan Province, Iran.

\section{Materials and methods}

The present study was conducted in an area about 42,000 hectares in the Rasht region, in the Guilan Province, located in north of Iran during 2015-2016 (Fig. 1). The study area is located $5 \mathrm{~km}$ West of the city of Rasht, between $49^{\circ} 31^{\prime}$ to $49^{\circ} 45^{\prime} \mathrm{E}$ longitude and $37^{\circ} 7^{\prime}$ to $37^{\circ} 27^{\prime} \mathrm{N}$ latitude in north of Guilan Province, the southern coast of Caspian Sea, Northern Iran. The Average annual temperature and precipitation for the period of 1987-2010 were $16{ }^{\circ} \mathrm{C}$ and $1294 \mathrm{~mm}$, respectively. Also, the annual evaporation of the area is $841 \mathrm{~mm}$. The Sefidrood River supplies the bulk of the water demands of the region. The application of irrigated agriculture has been common in the study area. Currently, the irrigation systems used by farmlands in the region is surface irrigation. Crop grown in this area are rice, canola and vegetables. We investigated satellite images, geology and topography maps of study area. The area is composed of Alluvial Plains. Soil characteristics were determined in laboratory. Eleven soil series were derived from soil study of the area. The soil series are shown in Fig. 2 as the basis for further land evaluation practice. The soils of the area are of Inceptisols and Entisols orders. Also, the soil moisture regimes are Udic and Aquic while the soil temperature regime is Thermic (Soil Survey Staff 2014b).

The land evaluation was determined based upon topography and soil characteristics of the region. The 


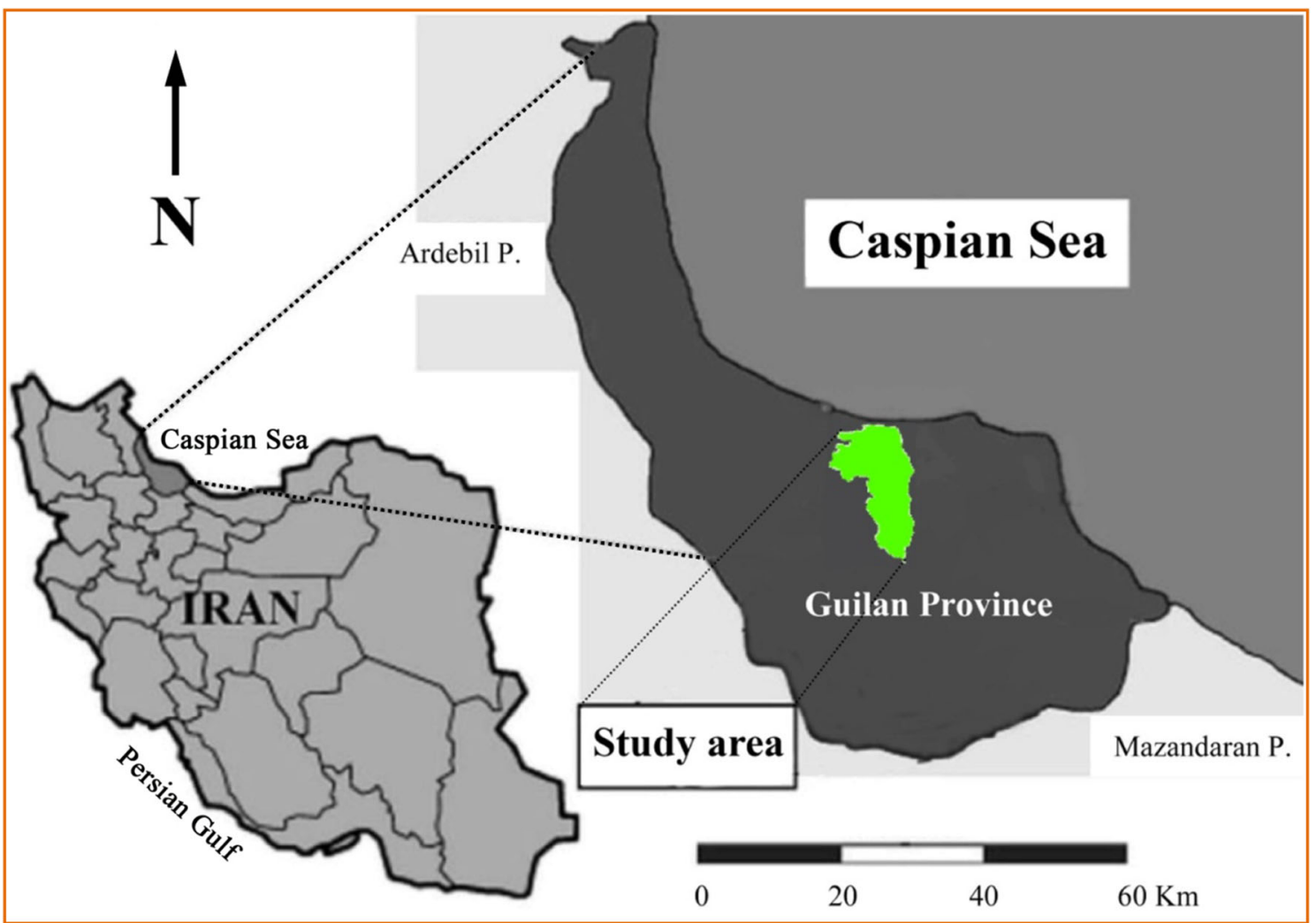

Fig. 1 Location of the study area

topographic characteristics included slope and soil properties such as soil texture, depth, salinity, drainage and calcium carbonate content were taken into account. Soil properties such as cation exchange capacity (CEC), percentage of basic saturation, organic matter $(\mathrm{OM})$ and $\mathrm{pH}$ were considered in terms of soil fertility. Sys et al. (1991) suggested that soil fertility characteristics can be excluded from land evaluation if it is done for the purpose of irrigation.

Samples were taken from each soil series profiles and laboratory analysis were carried out based on the conventional methods of the USDA (Soil Survey Staff 2014a), and the following properties were measured by due methods: Electrical conductivity (EC) in $\mathrm{dSm}^{-1}$ was calculated at $25^{\circ} \mathrm{C}$ on soil water $(1: 2)$ extract; the water soluble cations were calculated using the spectrophotometer method, the EC corresponds to the salinity, the soil texture was determined using the Gravimetric method (pipette). The proportional distribution of coarse sand $(2.0-0.2 \mathrm{~mm})$, medium sand $(0.2-0.1 \mathrm{~mm})$, fine sand $(0.1-0.05 \mathrm{~mm})$, coarse silt $(0.05-0.02 \mathrm{~mm})$, fine silt $(0.02-0.002 \mathrm{~mm})$, and clay $(<0.002 \mathrm{~mm})$ was calculated and successively the soil texture was classified using the USDA soil textural classification system. Lime $\left(\mathrm{CaCO}_{3}\right)$ in percentage is expressed as calcium carbonate equivalent using gas volumetric method (Soil Survey Staff 2014a).
The groups of soils that had similar properties and were located in a same physiographic unit were categorized as soil series and were classified to form a soil family as per the Soil Survey Staff (2014b). Ultimately, eleven soil series were selected for the surface, sprinkler and drip irrigation land suitability.

In order to obtain the average soil texture, salinity and $\mathrm{CaCO}_{3}$ for the upper $150 \mathrm{~cm}$ of soil surface, the profile was subdivided into six equal sections and weighting factors of $2,1.5,1,0.75,0.50$ and 0.25 were used for each section, respectively (Sys et al. 1991). For the evaluation of land suitability for surface, sprinkler and drip irrigation, the parametric evaluation system was used (Sys et al. 1991). This method is based on morphology, physical and chemical properties of soil. In parametric method, the land is evaluated according to numerical indexes. In this classification system, firstly a degree, whose rate is from 0 to 100 , is given to any land characteristic through comparing them with the tables of soil requirements. The specified degrees are used in order to measure the land index that is a multiplicative index that combines ratings assigned to soil map units and other physical conditions that affect the land use (Olsen 1981).

Parametric approach allows a calculation of a suitability index for irrigation considering some factors influencing the soil suitability. These factors are (Sys et al. 1991): 


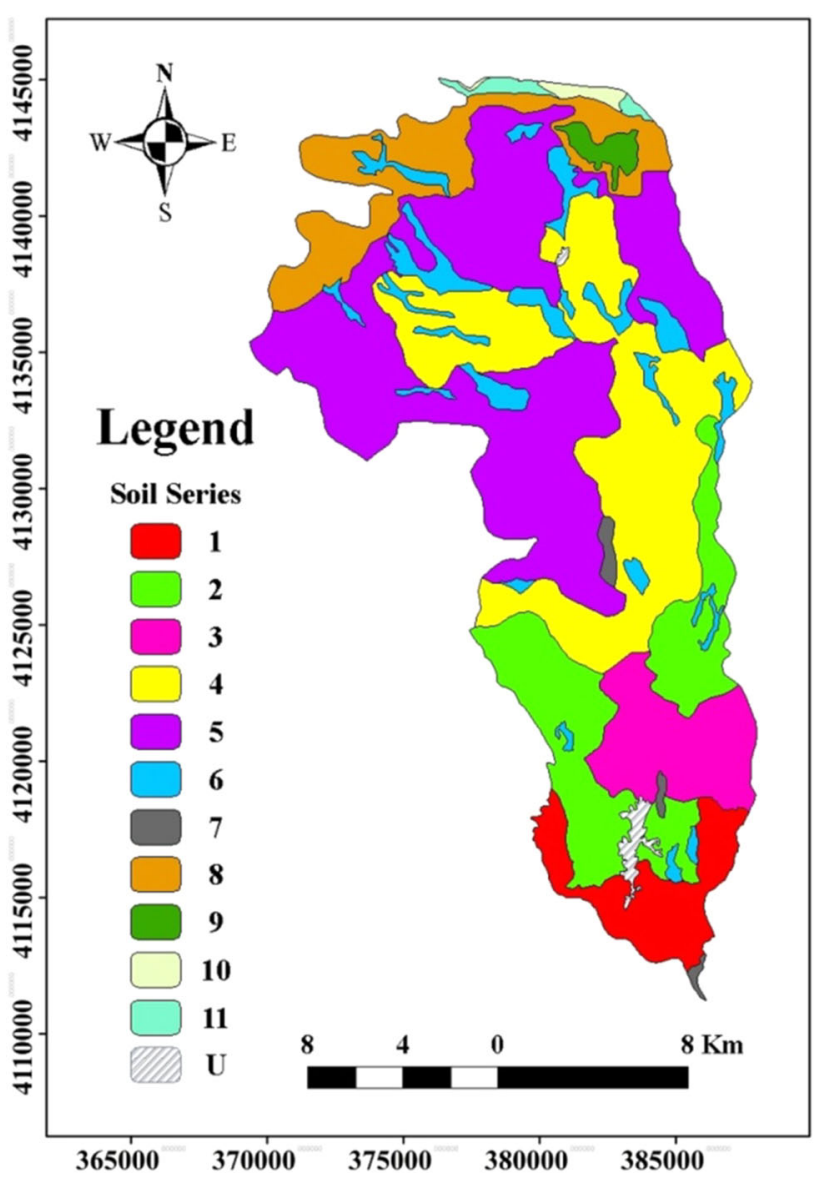

Fig. 2 Soil series map of the study area

- Soil texture rated taking into account the permeability and available water content, and calculated, as a weighted average, for the upper $100 \mathrm{~cm}$.

- Soil depth rated with regard to the thickness and characteristics of the soil layers (horizons).

- Calcium carbonate content influencing the relationship between soil and water, and the availability of nutrient supply for plants. It is rated with regard to the $\mathrm{CaCO}_{3}$ content effect on soil profile.

- Salinity rated on the base of the electrical conductivity of soil solution.

- Drainage a limiting factor when it is imperfect or weak. The rating for drainage is related to texture.

- Slope estimated considering the difference between terraced and non-terraced slopes.

These factors (including soil texture, soil depth, calcium carbonate content, electrical conductivity of soil solution, drainage properties and slope) were also considered and values were assigned to each as per the related tables (see Sys et al. 1991) for surface and drip irrigation and Albaji et al. (2009) for sprinkler irrigation). Thus, the capability index for irrigation (Ci) was developed as shown in the equations of methods below:
Storie method (Storie 1978):

$C i=A \times \frac{B}{100} \times \frac{C}{100} \times \frac{D}{100} \times \frac{E}{100} \times \frac{F}{100}$

where $\mathrm{A}$ is the rating of soil texture, $\mathrm{B}$ is the rating of soil depth, $\mathrm{C}$ is the rating of calcium carbonate content, $\mathrm{D}$ is the rating of electrical conductivity, $\mathrm{E}$ is the rating of soil drainage, $\mathrm{F}$ is the rating of soil slope. The capability index and the corresponding suitability classes are then ranked according to Table 1 .

Khidir method or square root (Khidir 1986):

$C i=A_{\min } \times \sqrt{\frac{B}{100} \times \frac{C}{100} \times \frac{D}{100} \times \frac{E}{100} \times \frac{F}{100}}$

where, $A_{\min }$ is the lowest rating in among of factors and $B-$ $F$ other factors ratings.

A soil series map (Fig. 2) was used, and all the data for the soil characteristics were analyzed and incorporated in the map using ArcGIS 10.3.1 software. The digital soil map base preparation was the first step towards the presentation of a GIS module for land suitability maps for different irrigation systems. The soil map was then digitized and a database prepared. A total of 11 different polygons or soil series were determined in the base map. Soil characteristics were also given for each soil series. These values were used to generate the land suitability maps for surface, sprinkler and drip irrigation systems using geographic information systems.

\section{Results}

The area is composed of alluvial flood plains physiographic features. Also, 11 different soil series have been identified in the area (Table 2). Table 3 shows some of physicochemical characteristics for reference profiles of the 11 different soil series in the plain. The land evaluation was determined based upon topography (soil slope) and soil characteristics, particularly soil texture, depth, salinity, drainage and calcium carbonate content.

Results obtained from Storie and Khidir methods were presented in Tables 4, 5 and 6. Comparison of used

Table 1 Suitability classes for the irrigation capability indices (Ci) classes

\begin{tabular}{lll}
\hline Capability index & Definition & Symbol \\
\hline$>80$ & Highly suitable & S1 \\
$60-80$ & Moderately suitable & S2 \\
$45-59$ & Marginally suitable & S3 \\
$30-44$ & Currently not suitable & N1 \\
$<29$ & Permanently not suitable & N2 \\
\hline
\end{tabular}


Table 2 Soil series of the study area

\begin{tabular}{|c|c|c|c|}
\hline \multirow[t]{2}{*}{ Series no. } & \multirow[t]{2}{*}{ Characteristics } & \multicolumn{2}{|l|}{ Area } \\
\hline & & ha & $\begin{array}{l}\text { Ratio } \\
(\%)\end{array}$ \\
\hline 1 & $\begin{array}{l}\text { Soil texture "Very Heavy: C", without salinity and alkalinity limitation. Depth } 200 \mathrm{~cm} \text {, level to very } \\
\text { gently sloping: } 0-1 \% \text {, imperfectly drained }\end{array}$ & 2414.08 & 5.86 \\
\hline 2 & $\begin{array}{l}\text { Soil texture "Heavy: SiCL", without salinity and alkalinity limitation. Depth } 250 \mathrm{~cm} \text {, level to very } \\
\text { gently sloping: } 0-2 \% \text {, poorly drained }\end{array}$ & 5419.99 & 13.16 \\
\hline 3 & $\begin{array}{l}\text { Soil texture "Very Heavy: C", without salinity and alkalinity limitation. Depth } 300 \mathrm{~cm} \text {, level to very } \\
\text { gently sloping: } 0-1 \% \text {, poorly drained }\end{array}$ & 2895.81 & 7.03 \\
\hline 4 & $\begin{array}{l}\text { Soil texture "Very Heavy: C", without salinity and alkalinity limitation. Depth } 270 \mathrm{~cm} \text {, level to very } \\
\text { gently sloping: } 0-2 \% \text {, poorly drained. }\end{array}$ & 9247.04 & 22.45 \\
\hline 5 & $\begin{array}{l}\text { Soil texture "Very Heavy: C", without salinity and alkalinity limitation. Depth } 300 \mathrm{~cm} \text {, level to very } \\
\text { gently sloping: } 0-1 \% \text {, poorly drained }\end{array}$ & $13,213.53$ & 32.08 \\
\hline 6 & $\begin{array}{l}\text { Soil texture "Heavy: CL", without salinity and alkalinity limitation. Depth } 250 \mathrm{~cm} \text {, level to very gently } \\
\text { sloping: } 0-2 \% \text {, Imperfectly drained }\end{array}$ & 2795.72 & 6.79 \\
\hline 7 & $\begin{array}{l}\text { Soil texture "Medium: SCL", without salinity and alkalinity limitation. Depth } 300 \mathrm{~cm} \text {, level to very } \\
\text { gently sloping: } 0-1 \% \text {, Imperfectly drained }\end{array}$ & 267.14 & 0.65 \\
\hline 8 & $\begin{array}{l}\text { Soil texture "Medium: SC", without salinity and alkalinity limitation. Depth } 280 \mathrm{~cm} \text {, level to very gently } \\
\text { sloping: } 0-2 \% \text {, very poorly drained }\end{array}$ & 3755.52 & 9.12 \\
\hline 9 & $\begin{array}{l}\text { Soil texture "Very Heavy: SiC", without salinity and alkalinity limitation. Depth } 300 \mathrm{~cm} \text {, level to very } \\
\text { gently sloping: } 0-1 \% \text {, very poorly drained }\end{array}$ & 398.18 & 0.96 \\
\hline 10 & $\begin{array}{l}\text { Soil texture "Light: LS", without salinity and alkalinity limitation. Depth } 150 \mathrm{~cm} \text {, level to very gently } \\
\text { sloping: } 0-2 \% \text {, well drained }\end{array}$ & 208.63 & 0.51 \\
\hline 11 & $\begin{array}{l}\text { Soil texture "Medium: L", without salinity and alkalinity limitation. Depth } 200 \mathrm{~cm} \text {, level to very gently } \\
\text { sloping: } 0-1 \% \text {, Imperfectly drained }\end{array}$ & 269.83 & 0.65 \\
\hline $\begin{array}{l}\text { Miscellaneous } \\
\text { land }\end{array}$ & Urban & 297.83 & 0.74 \\
\hline Total & & $41,181.31$ & 100 \\
\hline
\end{tabular}

Texture symbols $C$ clay, $S i C L$ silty clay loam, $C L$ clay loam, $S C L$ sandy clay loam, $S C$ sandy clay, $S i C$ silty clay, $L S$ loamy sand, $L$ loam

Table 3 Some physico-chemical characteristics for the reference profiles of different soil series

\begin{tabular}{lllllllll}
\hline Soil series no. & Soil series name & Depth $(\mathrm{cm})$ & Soil texture & $\mathrm{EC}\left(\mathrm{dSm}{ }^{-1}\right)$ & $\mathrm{pH}$ & $\mathrm{OM}(\%)$ & $\mathrm{CaCO}$ & $\mathrm{CEC}(\mathrm{meq} / 100 \mathrm{~g})$ \\
\hline 1 & Jobanah & 200 & $\mathrm{C}$ & 0.52 & 7.56 & 0.93 & 13.6 & 26.13 \\
2 & Roobordeh & 250 & $\mathrm{SiCL}$ & 0.73 & 7.59 & 1.33 & 18.36 & 26.34 \\
3 & Miandeh & 300 & $\mathrm{C}$ & 1.23 & 7.38 & 3.69 & 21.12 & 24.74 \\
4 & Tazehabad & 270 & $\mathrm{C}$ & 0.73 & 7.75 & 0.98 & 14.96 & 22.34 \\
5 & Galeshkhil & 300 & $\mathrm{C}$ & 1.17 & 7.25 & 4.02 & 13.12 & 20.42 \\
6 & Katehsar & 250 & $\mathrm{CL}$ & 0.49 & 7.62 & 3.08 & 16.92 & 20.07 \\
7 & Gishamandan & 300 & SCL & 1.23 & 7.65 & 0.77 & 17.91 & 16.64 \\
8 & Tuksarshijan & 280 & SC & 0.82 & 7.78 & 2.74 & 13.17 & 23.72 \\
9 & Sarkhoshki & 300 & SiC & 0.57 & 7.44 & 6.44 & 13.75 & 25.64 \\
10 & Fashtakeh & 150 & LS & 0.19 & 6.67 & 0.22 & - & 10.91 \\
11 & Jafrood & 200 & L & 1.17 & 7.58 & 3.59 & 12.12 & 21.5 \\
\hline
\end{tabular}

Texture symbols $C$ clay, $S i C L$ silty clay loam, $C L$ clay loam, $S C L$ sandy clay loam, $S C$ sandy clay, $S i C$ silty clay, $L S$ loamy sand, $L$ loam

methods showed that Khidir method was more accurate than Storie method because of calculated ratings by Khidir method were more than Storie method in all irrigation methods, on the other hand, Khidir method decreased interaction of factors with regard to Storie method, therefore we used Khidir method results for the selection of irrigation suitable system in this plain. As shown in Tables 4 and 6 for surface irrigation, no soil series were highly suitable; only soil series coded 1, 6, 7 and 11 (5746.78 ha, $13.95 \%)$ were classified as moderately 
Table $4 \mathrm{Ci}$ values and suitability classes of surface, sprinkler and drip irrigation for each land units

\begin{tabular}{|c|c|c|c|c|c|c|c|c|c|c|c|c|}
\hline \multirow{3}{*}{$\begin{array}{l}\text { Codes of } \\
\text { soil series }\end{array}$} & \multicolumn{4}{|c|}{ Surface irrigation } & \multicolumn{4}{|c|}{ Sprinkler irrigation } & \multicolumn{4}{|c|}{ Drip irrigation } \\
\hline & \multicolumn{2}{|c|}{ Storie method } & \multicolumn{2}{|c|}{ Khidir method } & \multicolumn{2}{|c|}{ Storie method } & \multicolumn{2}{|c|}{ Khidir method } & \multicolumn{2}{|c|}{ Storie method } & \multicolumn{2}{|c|}{ Khidir method } \\
\hline & $\mathrm{Ci}$ & $\begin{array}{l}\text { Suitability } \\
\text { classes }\end{array}$ & $\mathrm{Ci}$ & $\begin{array}{l}\text { Suitability } \\
\text { classes }\end{array}$ & $\mathrm{Ci}$ & $\begin{array}{l}\text { Suitability } \\
\text { classes }\end{array}$ & $\mathrm{Ci}$ & $\begin{array}{l}\text { Suitability } \\
\text { classes }\end{array}$ & $\mathrm{Ci}$ & $\begin{array}{l}\text { Suitability } \\
\text { classes }\end{array}$ & $\mathrm{Ci}$ & $\begin{array}{l}\text { Suitability } \\
\text { classes }\end{array}$ \\
\hline 1 & 56.70 & $\mathrm{~S} 3 \mathrm{w}$ & 63.00 & $\mathrm{~S} 2 \mathrm{w}$ & 60.75 & $\mathrm{~S} 2 \mathrm{w}$ & 67.50 & $\mathrm{~S} 2 \mathrm{w}$ & 64.6 & $\mathrm{~S} 2 \mathrm{w}$ & 71.89 & $\mathrm{~S} 2 \mathrm{w}$ \\
\hline 2 & 50.37 & S3w & 54.97 & S3w & 57.44 & S3w & 61.10 & $\mathrm{~S} 2 \mathrm{w}$ & 59.85 & S3w & 64.72 & $\mathrm{~S} 2 \mathrm{w}$ \\
\hline 3 & 49.36 & S3w & 54.42 & S3w & 53.48 & S3w & 58.96 & S3w & 56.52 & S3w & 62.90 & $\mathrm{~S} 2 \mathrm{w}$ \\
\hline 4 & 46.51 & S3w & 52.82 & S3w & 53.04 & S3w & 58.71 & S3w & 56.52 & S3w & 62.90 & $\mathrm{~S} 2 \mathrm{w}$ \\
\hline 5 & 49.29 & S3w & 54.38 & S3w & 53.39 & S3w & 58.91 & S3w & 56.52 & S3w & 62.90 & $\mathrm{~S} 2 \mathrm{w}$ \\
\hline 6 & 73.94 & $\mathrm{~S} 2 \mathrm{w}$ & 76.91 & $\mathrm{~S} 2 \mathrm{w}$ & 82.70 & $\mathrm{~S} 1$ & 83.84 & $\mathrm{~S} 1$ & 85.5 & S1 & 87.72 & $\mathrm{~S} 1$ \\
\hline 7 & 74.17 & $\mathrm{~S} 2 \mathrm{w}$ & 77.03 & $\mathrm{~S} 2 \mathrm{w}$ & 78.81 & $\mathrm{~S} 2 \mathrm{w}$ & 81.84 & $\mathrm{~S} 1$ & 81.22 & S1 & 85.5 & $\mathrm{~S} 1$ \\
\hline 8 & 29.03 & N1w & 34.07 & N1w & 40.82 & N1w & 42.86 & N1w & 45.12 & S3w & 47.5 & S3w \\
\hline 9 & 32.67 & N1w & 36.15 & N1w & 36.75 & $\mathrm{~N} 1 \mathrm{w}$ & 40.67 & N1w & 40.37 & $\mathrm{~N} 1 \mathrm{w}$ & 44.93 & N1w \\
\hline 10 & 47.70 & S3s & 51.22 & S3s & 63.91 & $\mathrm{~S} 2 \mathrm{~s}$ & 66.88 & $\mathrm{~S} 2 \mathrm{~s}$ & 77.60 & S2s & 81.22 & $\mathrm{~S} 1$ \\
\hline 11 & 68.47 & $\mathrm{~S} 2 \mathrm{w}$ & 74.01 & $\mathrm{~S} 2 \mathrm{w}$ & 72.75 & $\mathrm{~S} 2 \mathrm{w}$ & 78.63 & $\mathrm{~S} 2 \mathrm{w}$ & 76.95 & $\mathrm{~S} 2 \mathrm{w}$ & 83.22 & $\mathrm{~S} 1$ \\
\hline
\end{tabular}

Limiting factors for surface, sprinkler and drip irrigations: s: (soil texture) and w: (drainage)

Table 5 Distribution of surface, sprinkler and drip irrigation suitability classes (Storie method)

\begin{tabular}{|c|c|c|c|c|c|c|c|c|c|}
\hline \multirow{2}{*}{$\begin{array}{l}\text { Suitability } \\
\text { Class }\end{array}$} & \multicolumn{3}{|l|}{ Surface irrigation } & \multicolumn{3}{|c|}{ Sprinkler irrigation } & \multicolumn{3}{|l|}{ Drip irrigation } \\
\hline & $\begin{array}{l}\text { Codes of soil } \\
\text { series }\end{array}$ & Area (ha) & $\begin{array}{l}\text { Ratio } \\
(\%)\end{array}$ & $\begin{array}{l}\text { Codes of soil } \\
\text { series }\end{array}$ & Area (ha) & $\begin{array}{l}\text { Ratio } \\
(\%)\end{array}$ & $\begin{array}{l}\text { Codes of soil } \\
\text { series }\end{array}$ & Area (ha) & $\begin{array}{l}\text { Ratio } \\
(\%)\end{array}$ \\
\hline $\mathrm{S} 1$ & - & - & - & 6 & 2795.72 & 6.79 & 6,7 & 3062.86 & 7.42 \\
\hline $\mathrm{S} 2$ & $6,7,11$ & 3332.69 & 8.09 & $1,7,10,11$ & 3159.67 & 7.66 & $1,10,11$ & 2892.53 & 7.06 \\
\hline $\mathrm{S} 3$ & $1,2,3,4,5,10$ & $33,399.08$ & 81.09 & $2,3,4,5$ & $30,776.38$ & 74.73 & $2,3,4,5,8$ & $34,531.91$ & 83.84 \\
\hline N1 & 8,9 & 4153.71 & 10.08 & 8,9 & 4153.71 & 10.08 & 9 & 398.18 & 0.96 \\
\hline $\mathrm{N} 2$ & - & - & - & & & & - & - & - \\
\hline Urban & - & 297.83 & 0.74 & - & 297.83 & 0.74 & - & 297.83 & 0.74 \\
\hline Total & & $41,183.31$ & 100 & & $41,183.31$ & 100 & & $41,183.31$ & 100 \\
\hline
\end{tabular}

Table 6 Distribution of surface, sprinkler and drip irrigation suitability classes (Khidir method)

\begin{tabular}{|c|c|c|c|c|c|c|c|c|c|}
\hline \multirow{2}{*}{$\begin{array}{l}\text { Suitability } \\
\text { Class }\end{array}$} & \multicolumn{3}{|c|}{ Surface irrigation } & \multicolumn{3}{|c|}{ Sprinkler irrigation } & \multicolumn{3}{|l|}{ Drip irrigation } \\
\hline & $\begin{array}{l}\text { Codes of soil } \\
\text { series }\end{array}$ & Area (ha) & $\begin{array}{l}\text { Ratio } \\
(\%)\end{array}$ & $\begin{array}{l}\text { Codes of soil } \\
\text { series }\end{array}$ & Area (ha) & $\begin{array}{l}\text { Ratio } \\
(\%)\end{array}$ & $\begin{array}{l}\text { Codes of soil } \\
\text { series }\end{array}$ & Area (ha) & $\begin{array}{l}\text { Ratio } \\
(\%)\end{array}$ \\
\hline S1 & - & - & - & 6,7 & 3062.87 & 7.44 & $6,7,10,11$ & 3541.31 & 8.59 \\
\hline S2 & $1,6,7,11$ & 5746.78 & 13.95 & $1,2,10,11$ & 8312.51 & 20.17 & $1,2,3,4,5$ & 33190.45 & 80.59 \\
\hline $\mathrm{S} 3$ & $2,3,4,5,10$ & $30,984.99$ & 75.23 & $3,4,5$ & $25,356.39$ & 61.57 & 8 & 3755.52 & 9.12 \\
\hline N1 & 8,9 & 4153.71 & 10.08 & 8,9 & 4153.71 & 10.08 & 9 & 398.18 & 0.96 \\
\hline $\mathrm{N} 2$ & - & - & - & & & & & & \\
\hline Urban & - & 297.83 & 0.74 & - & 297.83 & 0.74 & - & 297.83 & 0.74 \\
\hline Total & & $41,183.31$ & 100 & & $41,183.31$ & 100 & & $41,183.31$ & 100 \\
\hline
\end{tabular}

suitable, soil series coded 2, 3, 4, 5 and 10 (30,984.99 ha, $75.23 \%$ ) were found to be marginally suitable. Soil series coded 8 and 9 (4153.71 ha, $10.08 \%$ ) were classified as currently not-suitable and no soil series were classified as permanently not-suitable for any surface irrigation practices.

The analysis of the suitability irrigation maps for surface irrigation (Fig. 3) indicates that the moderately 
suitable area is located in the south of this area and portions scattered in area due to drainage limitation. Other factors such as depth, salinity and alkalinity have no influence on the suitability of the area whatsoever. The map also indicates that the largest portion of the cultivated area in this plain was evaluated as marginally suitable because of the drainage limitation and light soil texture. The current nonsuitable lands can be observed only in the north of the plain because of the severe drainage limitation. For almost the total study area elements such as soil depth, salinity, slope and $\mathrm{CaCO}_{3}$ were not considered as limiting factors.

In order to verify the possible effects of different management practices, the land suitability for sprinkler and drip irrigation was evaluated (Tables $4 ; 6)$. For sprinkler irrigation, soil series coded 6 and 7 (3062.87 ha, $7.44 \%$ ) were highly suitable while soil series coded $1,2,10$ and 11 (8312.51 ha, $20.17 \%$ ) were classified as moderately suitable. Further, soil series coded 3, 4 and 5 (25,356.39 ha, $61.57 \%$ ) were found to be marginally suitable and only soil series coded 8 and 9 (4153.71 ha, $10.08 \%$ ) were classified as currently not-suitable for sprinkler irrigation. Regarding sprinkler irrigation (Fig. 4), the highly suitable area can be observed in some part of the cultivated

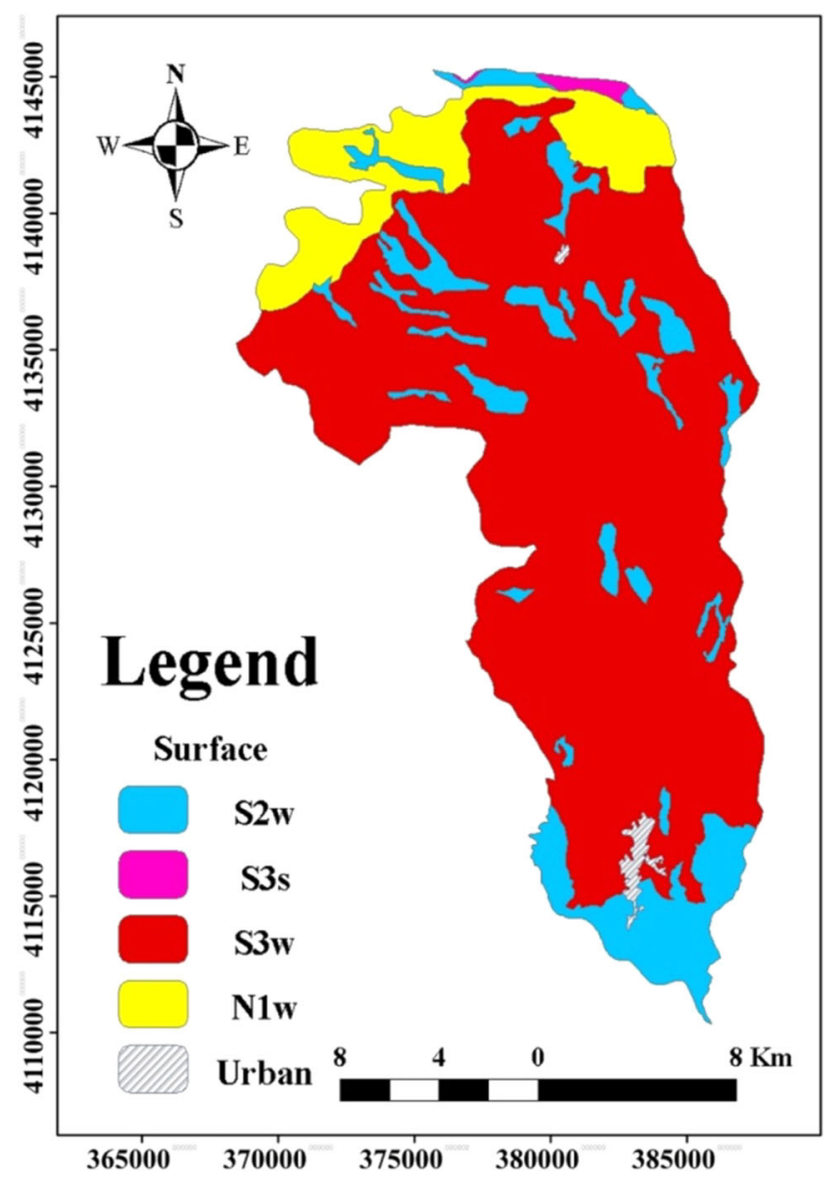

Fig. 3 Land suitability map for surface irrigation zone in this plain (located as scattered in area) due to deep soil, good drainage, texture, salinity and proper slope of the area. As seen from the map, some part of the cultivated area in this plain was evaluated as moderately suitable for sprinkler irrigation because of the light limitation of drainage and soil texture. Other factors such as calcium carbonate, soil depth, salinity and slope never influence the suitability of the area. The marginally suitable lands are located in the largest of the plain and their non-suitability of the land is due to drainage limitations. The current nonsuitable lands can be observed only in the north of the plain because of the severe drainage limitation. For almost the entire study area slope, soil depth, $\mathrm{CaCO}_{3}$ and salinity were never taken as limiting factors.

For drip irrigation, soil series coded 6, 7, 10 and 11 (3541 ha, $8.59 \%$ ) were highly suitable while soil series coded 1, 2, 3, 4, 5 (33190.45 ha, $80.59 \%$ ) were classified as moderately suitable. Further, soil series coded 8 (3755.52 ha, $9.12 \%$ ) was found to be marginally suitable. Only soil series coded 9 (398.18 ha, $0.96 \%$ ) was classified as currently nonsuitable for drip irrigation. Regarding drip irrigation (Fig. 5), the highly suitable lands covered the some part of the plain as scattered. The slope, soil texture, soil depth, calcium

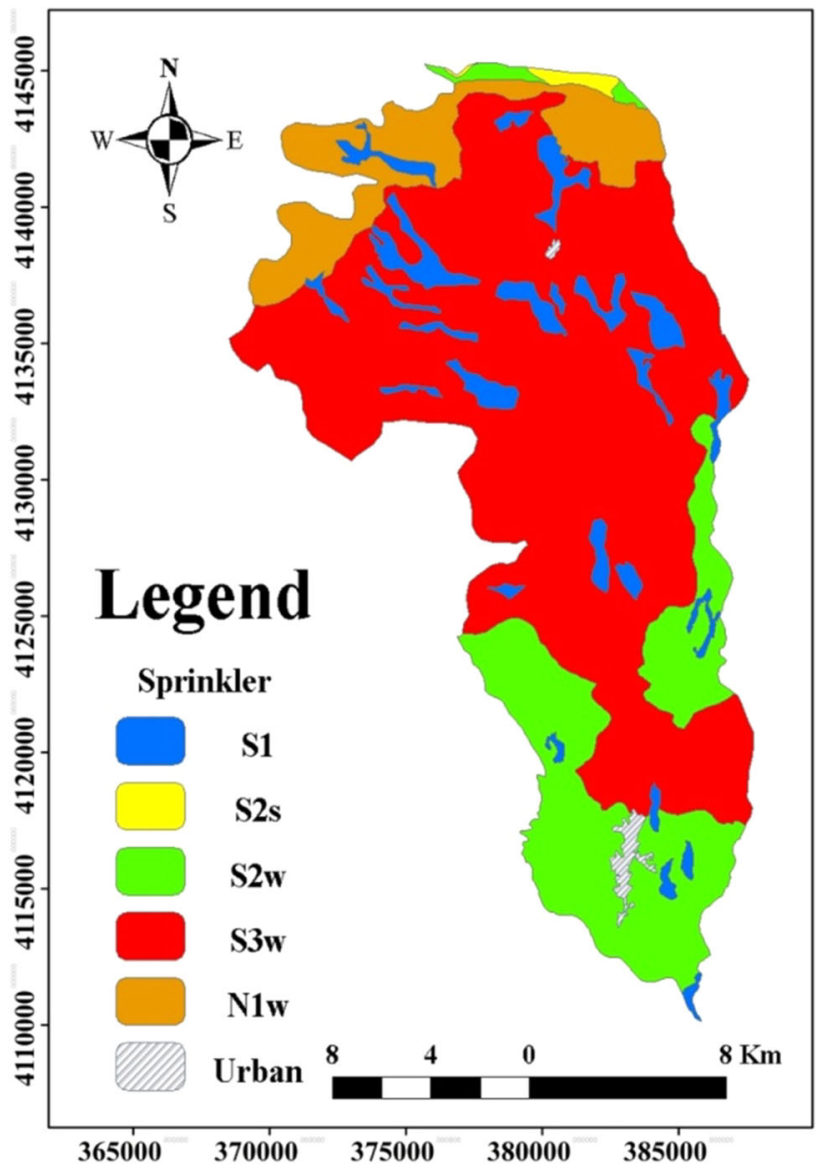

Fig. 4 Land suitability map for sprinkler irrigation 
carbonate, salinity and drainage were in good conditions. The moderately suitable lands could be observed in south and central parts of the plain due to the medium limitation of drainage. The marginally suitable lands were found in the smallest portion of the area. The limiting factor for this soil series was drainage limitation. The current non-suitable lands can be observed in the north of the plain because of very severe drainage limitation. For the entire study area slope, soil depth, soil texture, calcium carbonate and salinity were never considered as limiting factors.

The mean capability index for surface irrigation was 57.18 (marginally suitable, S3) while for sprinkler irrigation it was 63.63 (moderately suitable, S2). Moreover, for drip irrigation it was 68.67 (moderately suitable, S2). Tables 4 and 6 indicated that in all soil series applying drip irrigation systems were the most suitable option as compared to surface and sprinkler irrigation systems. Figure 6 shows the most suitable map for surface, sprinkler and drip irrigation systems in the Rasht Plain as per the capability index for different irrigation systems. As seen from this map, the all part of this plain was suitable for drip irrigation.

Tables 4 and 7 indicated that by applying drip irrigation instead of surface and sprinkler irrigation methods, the land

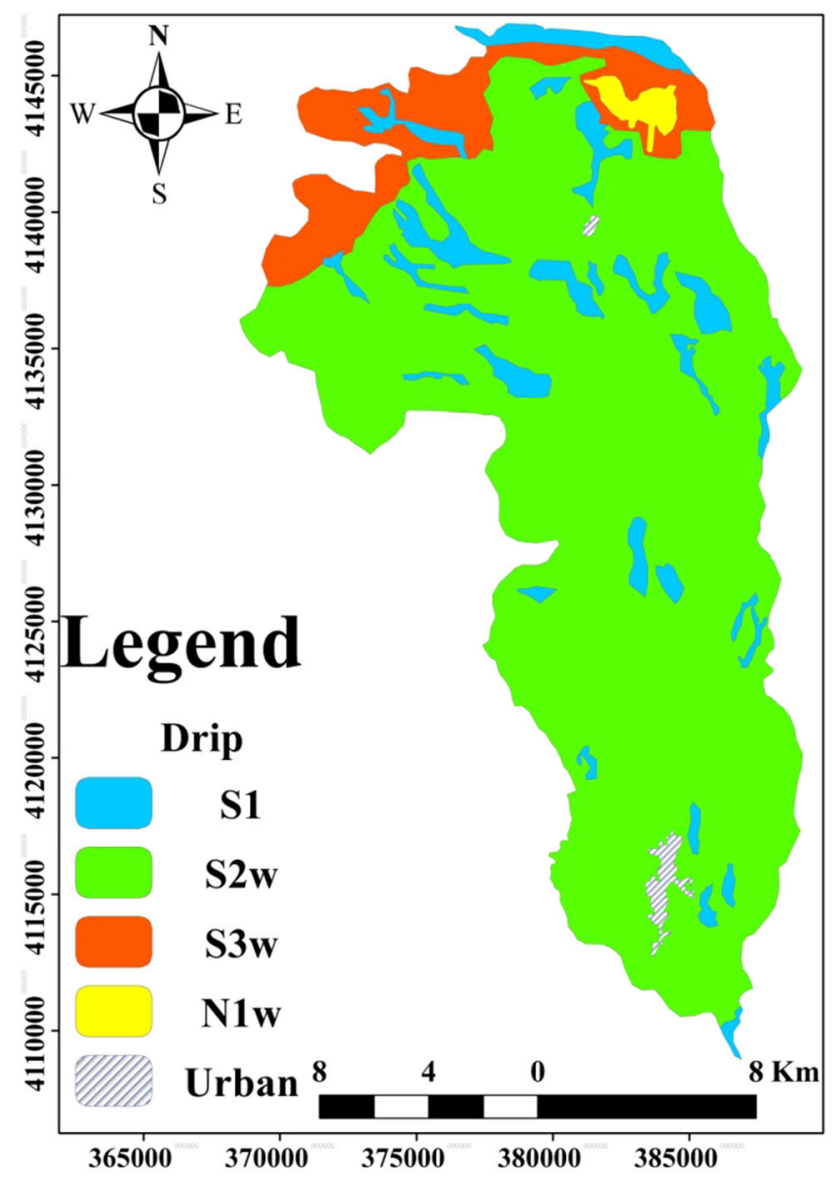

Fig. 5 Land suitability map for drip irrigation suitability of $40,487.3$ ha $(98.3 \%)$ of the Rasht Plain's land could be improved substantially. The comparison of the different types of irrigation revealed that drip irrigation was more effective and efficient than the sprinkler and surface irrigation methods and improved land suitability for irrigation purposes. The second best option was the application of sprinkler irrigation which was considered as being more practical than the surface irrigation method. To sum up the most suitable irrigation systems for the Rasht Plain were drip irrigation, sprinkler irrigation and surface irrigation, respectively. Moreover, the main limiting factor in using surface irrigation methods in this area were drainage and light soil texture and the main limiting factor in using sprinkler and drip irrigation methods was the severe drainage.

\section{Discussion}

Several parameters were used for the analysis of the field data in order to compare the suitability of different irrigation systems. The analyzed parameters included soil and land characteristics. The results obtained showed that drip

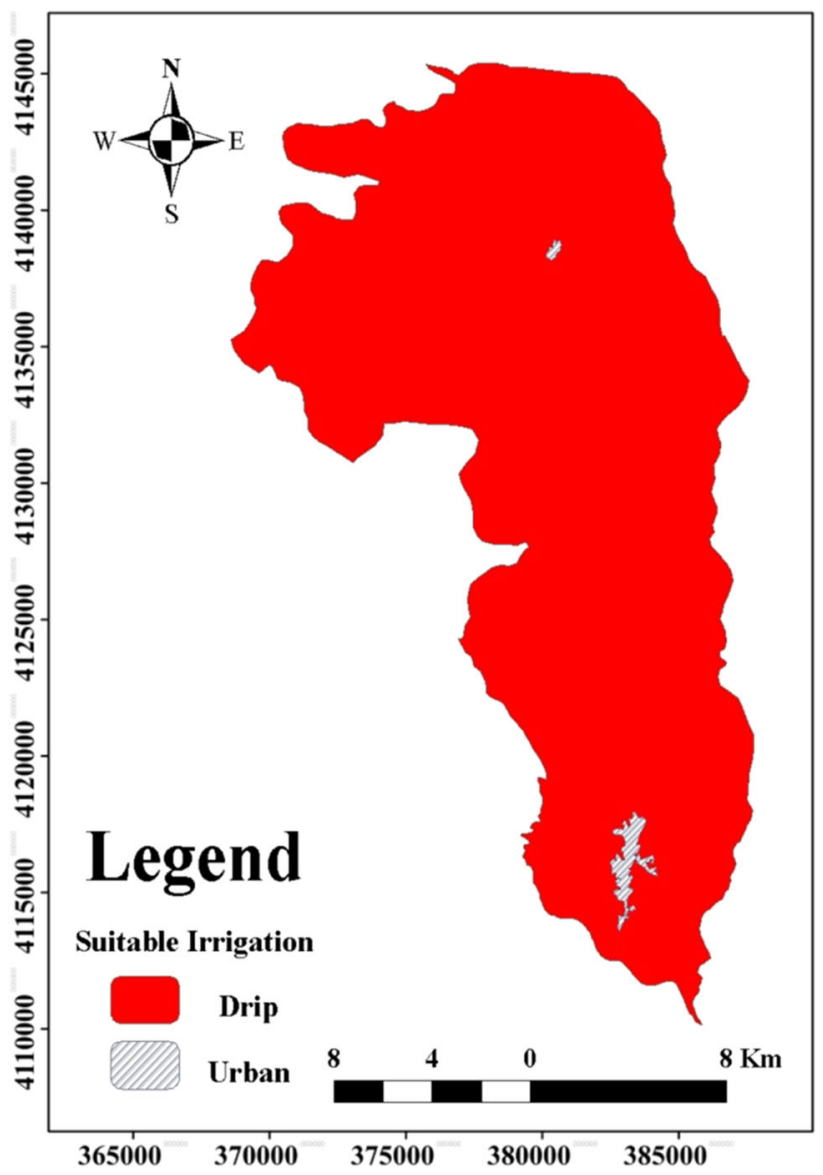

Fig. 6 The most suitable map for different irrigation systems 
Table 7 The most suitable soil series for surface, sprinkler and drip irrigation systems by notation to capability index $(\mathrm{Ci})$ for different irrigation systems (khidir method)

\begin{tabular}{lllll}
\hline $\begin{array}{l}\text { Codes of soil } \\
\text { series }\end{array}$ & $\begin{array}{l}\text { The maximum capability } \\
\text { index for irrigation }(\mathrm{Ci})\end{array}$ & $\begin{array}{l}\text { Suitability } \\
\text { classes }\end{array}$ & $\begin{array}{l}\text { The most suitable } \\
\text { irrigation systems }\end{array}$ & $\begin{array}{l}\text { Limiting } \\
\text { factors }\end{array}$ \\
\hline 1 & 71.89 & S2w & Drip & Drainage \\
2 & 64.72 & S2w & Drip & Drainage \\
3 & 62.90 & S2w & Drip & Drainage \\
4 & 62.90 & S2w & Drip & Drainage \\
5 & 62.90 & S2w & Drip & Drainage \\
6 & 87.72 & S1 & Drip & None exist \\
7 & S1 & Drip & None exist \\
8 & 85.5 & S3w & Drip & Drainage \\
9 & 47.5 & N1w & Drip & Drainage \\
10 & 44.93 & S1 & Drip & None exist \\
11 & 81.22 & S1 & Drip & None exist \\
\hline
\end{tabular}

irrigation system is more suitable than sprinkler and surface irrigation methods for most of the study area. This result is agreement with results from Rabia et al. (2013), Albaji et al. (2015) and Surendran et al. (2016). The major limiting factor in using surface irrigation methods in this area was drainage and soil texture and the main limiting factor in using sprinkler and drip irrigation methods was the severe drainage. The results of the comparison between the maps indicated that the introduction of a different irrigation management policy would provide an optimal solution such that the application of drip irrigation techniques could prove beneficial and advantageous. This is the current strategy adopted by large companies cultivating in the area and it will provide to be economically viable for Farmers in the long run. Such a change in irrigation management practices would imply the availability of larger initial capitals to farmers (different credit conditions, for example) as well as a different storage and market organizations. On the other hand, because of the insufficiency of water in this study area for surface irrigation, the optimization of water use efficiency is necessary to produce more crops per drop and to help resolve water shortage problems in the local agricultural sector. The shift from surface irrigation to high-tech irrigation technologies, e.g. drip irrigation system, therefore, offers significant water-saving potentials. On the other hand, since drip irrigation system typically apply lesser amounts of water (as compared with surface irrigations methods) on a frequent basis to maintain soil water near field capacity, it would be more beneficial to use drip irrigation method in this plain. In this study, an attempt has been made to analyze and compare three irrigation systems by taking into account various soil and land characteristics. The results obtained showed that drip irrigation method is more suitable than sprinkler and surface or gravity irrigation methods for most of the soils tested. Moreover, because of the insufficiency of surface and ground water resources in this area, drip irrigation method is highly recommended for a sustainable use of this natural resource; hence, changing of current irrigation methods from gravity (surface) to drip irrigation in the study area is proposed.

Acknowledgments This research was supported by Guilan University, Iran. The authors thank for laboratory assistance of soil science department technicians in university of Guilan. The authors are grateful to anonymous reviewers who considerably improved the quality of the manuscript.

\section{References}

Alam N, Olsthoorn TN (2011) Sustainable conjunctive use of surface and ground water: modeling on the basin scale. ECOPERSIA 1:1-12 (uuid:671c3fec-bcb5-4d54-ad36-48fc40b0e181)

Albaji M, Boroomand NS, Kashkoli HA, Naseri AA (2009) Comparison of different irrigation methods based on the parametric evaluation approach in the plain west of Shush, Iran. Irrig Drain 59(5):547-558. doi:10.1002/ird.520

Albaji M, Shahnazari A, Behzad M, Naseri AA, Boroomand NS, Golabi M (2010) Comparison of different irrigation methods based on the parametric evaluation approach in Dosalegh plain: Iran. Agri Water Manag 97:1093-1098. doi:10.1016/j.agwat. 2010.02 .015

Albaji M, Golabi M, Boroomand NS, Jahanshahi M (2014) Land suitability evaluation for surface, sprinkler and drip irrigation systems. T Roy Soc S Afr 69(2):63-73. doi:10.1080/0035919X. 2014.892038

Albaji M, Golabi M, Boroomand NS, Nazari ZF (2015) Investigation of surface, sprinkler and drip irrigation methods based on the parametric evaluation approach in Jaizan Plain. J Saudi Soc Agri Sci 14(1):1-10. doi:10.1016/j.jssas.2013.11.001

Asres SB (2016) Evaluating and enhancing irrigation water management in the upper Blue Nile basin, Ethiopia: the case of Koga large scale irrigation scheme. Agri Water Manag 170:26-35. doi:10.1016/j.agwat.2015.10.025

Azzat O, Hinojosa IG, Boris S, Molua MF, Keita A (2007) Land evaluation in Essaouira Province, Morocco. In: 27th Course Professional Master: geomatics and natural resources evaluation, Florence, Istituto Agronomico per l'Oltremare. https://www. 
yumpu.com/en/document/view/9996054/land-evaluation-inessaouira-province-morocco-istituto

Barberis A, Minelli S (2005) Land evaluation in the Shouyang County, Shanxi Province, China. In: 25th Course Professional Master: geomatics and natural resources evaluation, 8th Nov 2004-23rd Jun 2005, IAO, Florence, Italy. http://www.iao. florence.it/training/geomatics/Shouyang/China_25hq.pdf

Bazzani F, Incerti F (2002) Land evaluation in the Province of Larache, Morocco. In: 22nd Course Professional Master: geomatics and natural resources evaluation, 12th Nov 2001-21st June 2002, IAO, Florence, Italy. http://www.iao.florence.it/ training/geomatics/ Larache/Morocco-22.pdf

Bienvenue JS, Ngardeta M, Mamadou K (2003) Land evaluation in the Province of Thies, Senegal. In: 23rd Course Professional Master: geomatics and natural resources evaluation, 8th Nov 2002-20th June 2003, IAO, Florence, Italy. http://www.iao. florence.it/training/geomatics/Thies/senegal23.pdf

Briza Y, Dileonardo F, Spisni A (2001) Land evaluation in the Province of Ben Slimane, Morocco. In: 21st Course Professional Master: remote sensing and natural resource evaluation, 10th Nov 2000-22nd June 2001, IAO, Florence, Italy. http://www.iao. florence.it/training/geomatics/BenSlimane/Marocco21.pdf

Brou YB, Woldegiorgis HS (2010) Land evaluation in Kilte Awulaelo District, Tigray Region, Ethiopia. In: 29th Course Professional Master: Geomatics and Natural Resources Evaluation, Florence, Istituto Agronomico per l'Oltremare

Dengiz OA (2006). Comparison of different irrigation methods based on the parametric evaluation approach. Turk J Agric For 30:21-29. http://dergipark.ulakbim.gov.tr/tbtkagriculture/article/ view/5000027203

Diouf OC, Sarr NP (2011). Land evaluation in Sant'Antioco Island, Southern Sardinia, Italy. In: 31st Course Professional Master: geomatics and natural resources, Florence, Istituto Agronomico per l'Oltremare. http://www.iao.florence.it/training/geomatics/ Report.php

Fernandez Garcia I, Moreno MA, Rodriguez Diaz JA (2014) Optimum pumping station management for irrigation network sectoring: case of Bembezar MI (Spain). Agri Water Manag 144:150-158. doi:10.1016/j.agwat.2014.06.006

Food and Agriculture Organization of the United Nations (FAO) (1976) A framework for land evaluation. Soil Bulletin 32, FAO, Rome, Italy, pp 72. http://www.fao.org/docrep/x5310e/ x5310e00.HTM

Gizachew AA, Ndao M (2008). Land evaluation in Enderta District, Tigray, Ethiopia. In: 28th Course Professional Master: geomatics and natural resources evaluation, Florence, Istituto Agronomico per l'Oltremare. doi:server.iao.florence.it/iaolegacy/training/geo matics/Mekele/28_Ethiopia.pdf

International Federation of Agricultural Producers. (2005) Good Practices in Agricultural Water Management, Case Studies from Farmers Worldwide. United Nations, Department of Economic and Social Affairs. www.un.org/esa/sustdev/csd/csd13/docu ments/bground_3.pdf

Khidir SM (1986) A statistical approach in the use of parametric systems applied to the FAO framework for land evaluation. $\mathrm{Ph} . \mathrm{D}$. Thesis, State University of Ghent, Belgium, pp 141

Liu W, Qin Y, Vital L (2006) Land evaluation in Danling county, Sichuan Province, China. In: 26th Course Professional Master: geomatics and natural resources evaluation, 7th Nov 2005-23rd Jun 2006, IAO, Florence, Italy. http://www.iao.florence.it/ training/ geomatics/Danling/China-26.pdf

Mbodj C, Mahjoub I, Sghaiev N (2004). Land evaluation in the Oud Rmel Catchment, Tunisia. In: 24th Course Professional Master: geomatics and natural resources evaluation, 10th Nov 2003-23rd Jun 2004, IAO, Florence, Italy. http://www.iao.florence.it/ training/geomatics/Zaghouan/Tunisia-24lq.pdf

Olsen GW (1981) Soils and the environment. Chapman and Hall Press, New York

Panda RK, Behera SK, Kashyap PS (2004) Effective management of irrigation water for maize under stressed conditions. Agri Water Manag 66(3):181-203. doi:10.1016/j.agwat.2003.12.001

Rabia AH, Figueredo H, Huong TL, Lopez BAA, Solomon HW, Alessandro V (2013) Land suitability analysis for policy making assistance: a GIS based land suitability comparison between surface and drip irrigation systems. Int $\mathrm{J}$ Environ Sci Dev 4(1):1-6. doi:10.7763/IJESD.2013.V4.292

Samian M, Naderi Mahdei K, Saadi H, Movahedi R (2015) Identifying factors affecting optimal management of agricultural water. J Saudi Soc Agri Sci 14:11-18. doi:10.1016/j.jssas.2014. 01.001

Soil Survey Staff (2014a) Kellogg soil survey laboratory methods manual. Soil Survey Investigations Report No. 42, Version 5. Burt R and Soil Survey Staff (ed). United States Department of Agriculture, Natural Resources Conservation Service. http:// www.nrcs.usda.gov/Internet/FSE_DOCUMENTS/ stelprdb1253871.pdf

Soil Survey Staff (2014b) Keys to Soil Taxonomy. In: 12th ed. United States Department of Agriculture, Washington D.C., USA. http:// www.nrcs.usda.gov/Internet/FSE_DOCUMENTS/nrcs142p2_ 050915.pdf

Storie RE (1978) Storie index soil rating. University of California, Division of Agricultural Sciences Special Publication, No. 3203, Oakland, USA. http://anrcatalog.ucanr.edu/pdf/3203.pdf

Surendran U, Jayakumar M, Marimuthu S (2016). Low cost drip irrigation: impact on sugarcane yield, water and energy saving in semiarid tropical agro ecosystem in India. Sci Total Environ http://dx.doi.org/10.1016/j.scitotenv.2016.07.144 (In Press)

Sys C, Van Ranst E, Debaveye J (1991) Land evaluation, part I: principles in land evaluation and crop production calculations. International Training Centre for Post-graduate Soil Scientists, University of Ghent, Belgium. https://library.wur.nl/isric/full text/isricu_i10638_001.pdf 